\title{
Media Exposure of Novel Protests: Domestic Femininity in News Coverage of the Great Railway Adventure Protests
}




\begin{abstract}
$\underline{\text { Abstract }}$
Social Movements often incorporate masculinity into protest events as a means of achieving media attention. This attention is then used to mobilize, increase membership and generate social and political outcomes. This paper explores the media attention potential of novel social movement actions that deal with 'domestically feminine' elements of protest. This paper examines the case of the Great Railway Adventure, a series of protests in England organized by the Craftivist Collective and Climate Rush incorporating feminine dress, craftwork and food. It analyzes the success of these tactics in generating media attention through these tactics and the role the tactics play in the framing of protests in the news media. By employing a qualitative content analysis of the media, I found that the tactics were able to achieve limited levels of media attention through novelty and situational irony when done in combination with more standard elements of direct action campaigning.
\end{abstract}

Keywords:

social movements, media, femininity, protest, domestic, transportation, England, direct action, suffragettes, craft 


\section{$\underline{\text { Introduction }}$}

Prior to and during the women's suffrage movement of the late $19^{\text {th }}-$ early $20^{\text {th }}$ century in Britain, publications targeting middle class urban and rural women emphasized a particular femininity. Publications such as Good Housekeeping, Woman and Home, and the 'home' sections of Farmer and Stockbreeder and Farmers Weekly focused on topics including recipes and dress patterns, evolving over time to include healthcare, childrearing and wildlife (Verdon 2010, pp.88-9). One female columnist for the Farmers Weekly (quoted in ibid p.89) noted that she 'did not expect men "to become wildly enthusiastic about details of cooking, knitting, fashions and matters of more essentially feminine interest"'. These 'more essentially feminine interests' are reflected in other literature written for women at the time. 'Mrs. John Ferrar's' The Young Lady's Friend (1985) states that women's 'express vocation' is 'good housekeeping' (ibid p.3) citing examples: 'assist at the ironingtable, or in making cake and pies...or in making preserves....or hemming a pocket handkerchief' (ibid p.37). Although feminine tropes presented through these works were challenged in other texts and by women at the time (see Verdon 2010), they represented the common depiction of women in the 1800s in the UK and the US (Peirce 1997, p.583; Welter 1966).

While these stereotypes have morphed over time, they represent a traditional femininity that has not entirely gone away. This paper examines a serious of protest events that actively toyed with this stereotype during an attempt to change government policy on train 
fares. By using craft, cooking, and clothing in combination with direct action, these protests exemplified women of this earlier epoch, while highlighting representations of Suffragettes' militancy (Mayhall 1995). In part, these organizations utilized this novel 'clash' of the domestic and the militant in order to reach wider audiences and attract greater attention to their cause. Here, using qualitative content analysis, I explore the effects these tactics had on shaping news stories surrounding the protests to see just what effect they did have on media framing and attention, two important aims for social movements.

\section{$\underline{\text { Social Movements, Tactics, and Media Attention }}$}

The social movement literature has maintained an interest in policy outcomes (eg Giugni 2004; Burstein 1999; Gaventa and McGee 2010), for several decades, with media attention increasingly playing a substantive role in the literature (eg Kolb 2007, Giugni 1998, 2004). Scholars have argued that media attention can be used as a way to bring about change in public opinion and issue salience (Kolb 2007; Soroka 2003; Burstein 1998, 2003; Burstein and Linton 2002; Giugni 1998) through the use of framing and exposure. Some have even argued that 'the only real means of influencing policies most social movements have apart from those movements that have become political "insiders" or that have the power to disrupt social and political life - is playing on public opinion' (Vliegenthart and Walgrave 2012: 388), and that public opinion change occurs in large part through interactions via mass media. 
By appealing to a significant number of voters or an important voting bloc and maintaining an issue's level of importance for the voting population, social movements can pressure policymakers to settle voter concerns. Having an indirect impact of policy outcomes through a more direct impact of issue salience and public opinion requires significant attention, often through the mass media (Gamson and Modigliani 1989; de Vreese and Boomgaarden 2006). This is sometimes referred to as the public preference mechanism (Kolb 2007).

In order to achieve media exposure social movements "have to "demonstrate" in different ways - by staging events, mobilizing publics...or by making valid claims - that they are newsworthy' (Vliegenthart and Walgrave 2012: 387). And, despite the upsurge in social media (Beer 2006) and citizen journalism (Watson 2011), social movements are still 'dependent on the mass media to get their message across' (Vliegenthart and Walgrave 2012: 388; also see van Zoonen 1992:453).

In order to get media attention, activists often have to resort to WUNC displays. As described by Charles Tilly (2006), WUNC 'sounds odd, but it represents something quite familiar. WUNC displays can take the form of statements, slogans, or labels that imply worthiness, unity, numbers, and commitment' (Tilly 2006: 54).

While social movement scholars have examined media attention (eg van de Donk et al. 2004; Carrol and Ratner 1999; King and Soule 2007; Gitlin 2003; Oliver and Myers 1999; Cottle 2008; also see Vliegenthart and Walgrave 2012) and critiqued research based on newspaper accounts (eg Earl et al. 2004), less research has focused on the framing of 
particular tactics and specific elements of protest in the media. Such investigations can illuminate the potential for the use of specific tactics to achieve positive media attention and attract media coverage.

I use the Great Railway Adventure to investigate a particular set of protest components termed 'domestically feminine elements' (DFEs) to see whether they play a role in framing and attract mass news media. The Great Railway Adventure was a series of protest events that included direct action and civil disobedience calling on government to stop or minimize increases of train ticket prices in the United Kingdom. Although the demands of the campaign seem ordinary, elements of these actions were novel. These elements included forms of femininity, particularly activities associated with the domestic sphere. I refer to these feminine actions as DFEs, which have been discussed in reference to other protest events in the UK (see Andrews 1997; Cresswell 1994; Young 1990). Specifically, I will consider protest elements to be domestically feminine when they include elements of homemade craft, cooking, and clothing. I also examine the interaction between WUNC displays and these DFEs.

DFEs, I hypothesize, can be helpful in drawing significant attention and support if combined with more traditional elements of protest that attract media attention. Primarily these elements are either (1) disruptive or (2) spectacular protest (Gamson and Wolfsfeld 1993), due to the DFEs ability to strengthen WUNC displays. The inclusion of more traditional elements allow for concision (see Dellinger 1999), providing an easy introduction of the novel act through an existing media frame of standard protest. At the same time, the novel elements are used to justify media publication (see Patterson 1997) ${ }^{1}$. 


\section{What was the Great Railway Adventure?}

In 2011, the Association of Train Operating Companies threatened to increase train fares by 5.9 percent, after the government capped its increase at 6 percent (BBC News 2011). While the government has the power to cap the cost of average increases in train ticket prices, the trains themselves are private. The government had a wave of privatization of public services since Margaret Thatcher came to power in 1979. Despite having privatized bus and coach services, it was not until 1993 that significant moves were made toward privatization of the publically-owned train industry, British Rail. Its full privatization came before the 1997 general election, after which Tony Blair and the Labour Party won back the government from longstanding control by the centre-right Conservatives (Glaister 2004). However, Tony Blair's new Labour policies conflicted with the ideology of nationalization and his government instead focused on regulation.

The Great Railway Adventure was a series of protest actions put together by several organizations (Climate Rush and the Craftivist Collective, with the help of Fair Fares Now and Bring Back British Rail), which attempted to reduce or curb increasing train fares in the United Kingdom.

In fighting the recent train fare increases, campaigning groups had different approaches, with Bring Back British Rail calling for 'the reintegration of the country's rail network so that it is unified as one organisation with a common goal of providing the best value, most efficient and reliable public transport system possible' (Bring Back British Rail nd). The Fair Fares Now campaign, part of Campaign for Better Transport, called on the 
government to intervene and regulate fare increases (Campaign for Better Transport nd). Despite their different strategic approaches these two organizations, with the help of others, put together a series of protest events in an attempt to affect policy and reduce train fare increases.

Climate Rush, one of the organizations involved in the protest, is a direct action group seeking to mitigate and adapt to climate change with the added twist that they are inspired by Suffragettes, the label given to members of the movement for women's right to vote (1872 - 1928) in the UK. Climate Rush actions involve participants wearing clothing reminiscent of the early 1900s and red campaign sashes advertising their cause, resembling the campaigning style of the Suffragettes. While the Suffragettes themselves used femininity as a political tool in their campaigning (Stewart 2005) in part by subverting Western forms of femininity through their use of direct action and frequently militant tactics (see eg Raeburn 1973), Climate Rush's deployment of these elements connects the two seemingly distinct political goals of suffrage and climate change mitigation/adaptation, in addition to bringing an element of carnival to the protest. The group had previously campaigned to oppose new coal, airport expansion and to reform climate change policy (Climate Rush nd; also see Sparrow 2009; van der Zee 2009; Daily Mail 2009; Jackson 2011).

The fourth organization, which completed the network of campaign organizers, was the Craftivist Collective, a multi-issue group of craft/activists who use their interest in sewing, knitting, stitching and other forms of craft as a tactical contribution to various causes. In their words, they are 'activists who protest using scissors, thread and fabric' (Craftivist 
Collective 2011b). The group was founded by Sarah Corbett who started craftivism projects in 2008 under the name 'A Lonely Craftivist' as a reaction to activist 'burnt-out', feeling out of place in activist circles, and desiring the alteration of existing repertoires of contention. Generally, the Collective works on craft projects to convey political messages using handmade objects often associated with the domestic sphere (Mason 2005).

Although the Craftivist Collective and Climate Rush emphasis DFEs, neither organization prohibits the participation of men in their events or organization. Both groups include male members and males participated in the Great Railway Adventure.

\section{Methodology}

I explore the variety of DFEs used in the protest which were based on participatory observation (see eg Atkinson and Hammersley 1994) conducted at the Unfair Fare Dodge, the climax of the Adventure campaign. Then I analyze the impact of the use of DFEs on the framing of news articles about the protests.

I first did this by collecting news articles using Nexis® UK. I searched for the terms ‘protest' OR ‘demonstration’ AND ‘train’ OR 'fare' OR 'rail' AND ‘Climate Rush’ OR 'Craftivist' OR 'stitch', between the March 1, 2011 (the month of the first post on the Railway Adventure blog (http://railwayadventure.wordpress.com/) and May 31, 2011 (the month in which protesters presented a petition to Secretary of State for Transport Philip Hammond) in all UK publication ${ }^{2}$. I then proceeded to use qualitative content analysis, specifically employing a directed content analysis (see Hsieh and Shannon 2005) which looks to apply existing theory to given textual readings. Following this, I coded the text of 
each article (ten, with six unrelated article removed) regarding the appearance of DFEs and was interested in the context they are presented in, and their role within framing the news article as a whole.

\section{$\underline{\text { Summary of protest events }}$}

Within The Great Railway Adventure, femininity was used through actions associated with the domestic elements of crafting, baking, and dress. The DFEs were predominately used by Craftivist and Climate Rush activists to differing degrees at different protest events which made up the campaign. These events were composed of stitch-ins and a direct action event called the Unfair Fare Dodge. However, events that took place prior to the official launch of the campaign help to frame the protests.

\section{$\underline{\text { Lead-Up Protest Events }}$}

Prior to the organizations campaigning together, Climate Rush had its own actions regarding rail fare increases. The first took place on 18 October, 2010 and was a presentation of an imitation axe to the Department for Transport. A sign draped on the axe read 'AXE WIELDING BEECHAM [sic] STRIKES AGAIN', in reference to the 1963 and 1965 government reports on railways referred to as the Beeching Axe, that led to a massive number of railway line closures. As with many Climate Rush events there were a large proportion of activists dressed in Victorian/Edwardian-inspired clothing.

Later, Climate Rush activists delivered a message to Secretary of State for Transport Philip Hammond asking him to support the protest and join the campaign the following weekend (Climate Rush 2011). The activists dressed up in Edwardian style clothing as characters 
from a famous British children's novel and film, The Railway Children (Nesbitt 1993) that inspired the campaign's name and which was referred to throughout the different protest events (see image 1).

Image 1 - Example of Edwardian costumes used in protest

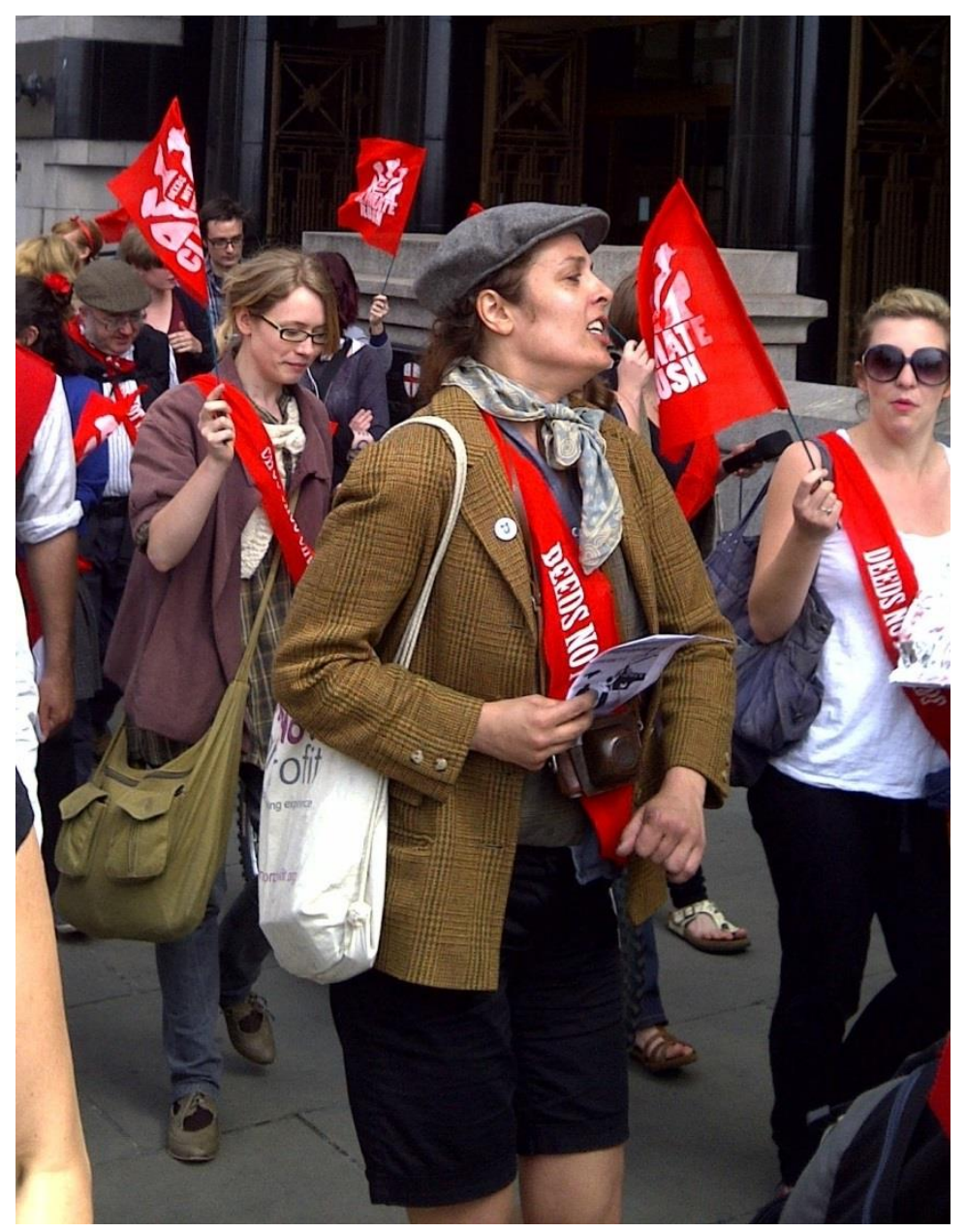

$\underline{\text { Stitch-Ins }}$

In the first major action of the Railway Adventure campaign, Craftivist Collective members gathered and stitched messages detailing 'stats, facts, quotes, views on the 
devastating effects that train fare hikes will have on the nation and world' (Craftivist Collective 2011a) onto fabric shaped to look like train cars. These individual stitched passenger cars (see image 2) were crafted together to form a visual petition-train to be used in later actions. These were known as stitch-ins, named after the sit-ins of the civil rights movements (Lawson 1991).

The most prominent 'stitch-in' events in the campaign occurred simultaneously at several different train stations around England. This day of stitch-ins featured 'craftivists' participating in some level of civil disobedience by holding picnics at their respective station against the wishes of station authorities, all while attracting public attention through collective stitching. These stitch-ins took place in Brighton, Cornwall, Dorset, Devon, Leeds, Sheffield, Manchester and London. One craftivist stated: 'It was a great way to engage the public in the issues of unfair rail fares and climate change. We crafted loads of train coaches to add to our [petition-train] during the day. And which other protest could you attend that provides jam sandwiches, cupcakes and tea with a smile?' (Craftivist Collective 2011b).

The protest events described above can be seen as the build up to the Unfair Fare Dodge, the campaign's central protest event that included a rally and civil disobedience where participants boarded a train from London without purchasing a full-price ticket and travelled to the city of Canterbury where proposed fares were to be increased the most. The following is a description of the event based on participant observation made by the author. 
Image 2 - Example of stitched passenger car reading: 'Choo-choosing the train rather than the plane cuts $\mathrm{CO} 2$ emissions by over $90 \%$ '

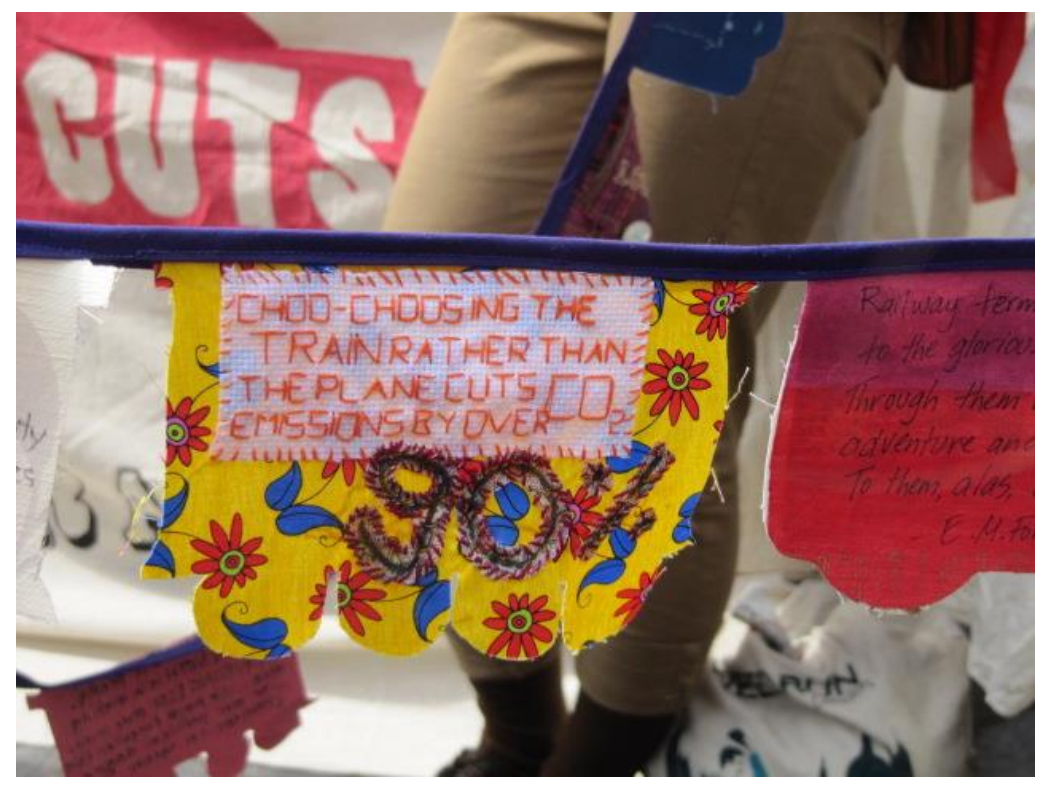

The Unfair Fare Dodge

The Unfair Fare Dodge occurred on 16 April, 2012. It was organized primarily by Climate Rush and began with a rally where participants were given Climate Rush's trademark sashes as well as red flags with the group's logo and slogans such as 'Deeds Not Words', borrowed from the suffragettes. Again, many activists showed up in Edwardian-inspired clothing. Once the group of approximately 50 people had gathered, speeches were made by members of Climate Rush and Fair Fares Now. They also read from The Railway Children book. This was followed by the unveiling of the stitched petition-train which the stitch-ins had produced (see image 3). Approximately 10 of the 50 people were males who mostly stood in the back of the assembled rally. 
Image 3 - Petition-train formed from individual stitched passenger cars

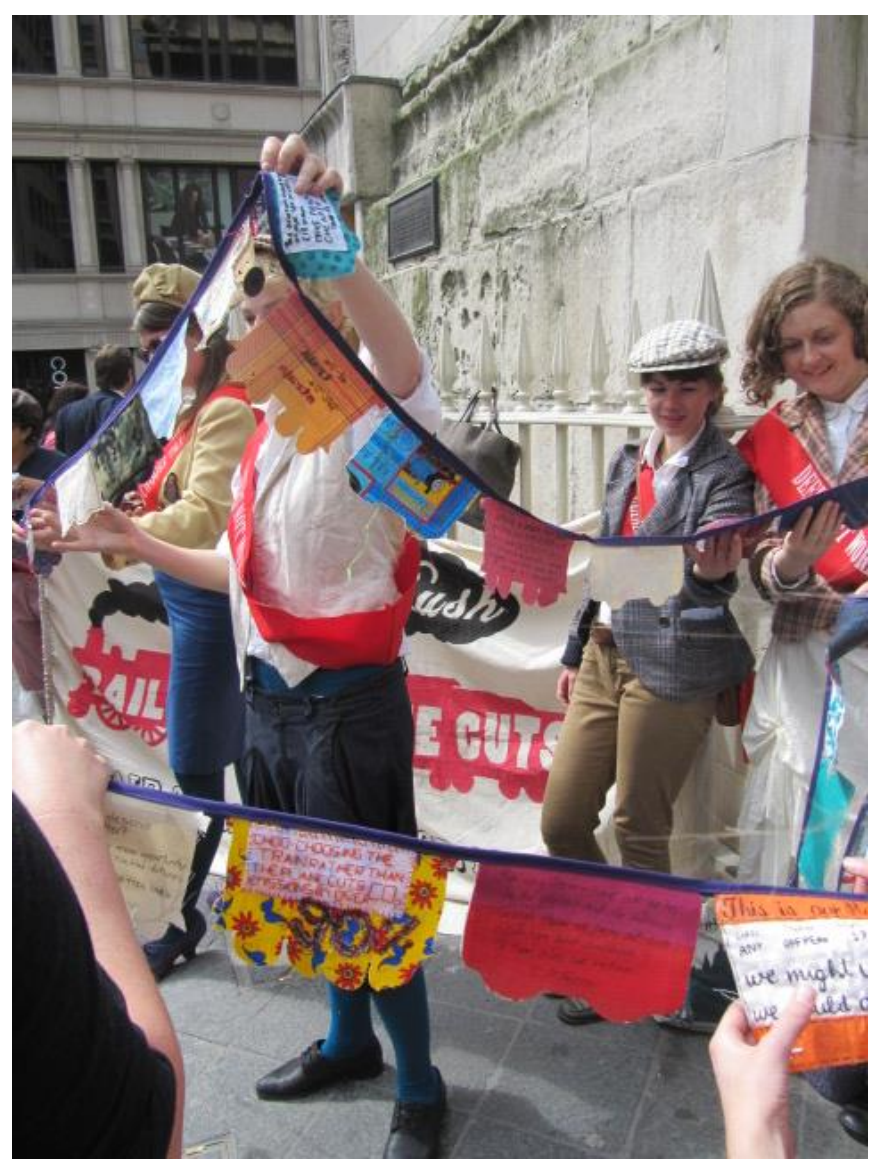

After the rally, participants marched to a nearby train station. Here the plan was to use prepaid 'Oyster' cards which would allow the protesters to get on the train to Canterbury without paying the normal fare of over $£ 25$. The protesters believed that this was legal as long as they did not leave the train station in Canterbury but returned to the station at which they originally boarded. They accepted to pay a penalty of just over $£ 7$ upon returning to the original station, arguing that $£ 7$ was the equivalent fare for a journey of the same length in many countries in continental Europe. Waiting for the next train to arrive, 
there was an impromptu picnic held in front of the train station where many of those taking part had made or bought cakes, jam sandwiches, tea and lemonade, which they shared with other participants.

Once it was time to go onto the platform and board the train, several participants decided to stay behind, not wishing to take part in this form of civil disobedience for individual reasons. In total, approximately 35 people participated in the civil disobedience and 15 stayed behind. After boarding, participants decorated the train with the 25-meter long stitched petition-train. Some protesters on board served tea and handed out sandwiches to others in the passenger car, including those not participating in the action. Activities during the journey comprised of leafleting Fair Fares Now materials to train travelers in other cars, meeting other activists, singing, stitching and reading aloud from The Railway Children (see image 4). Though there were 'Ticket Enforcement Officers' onboard they made no attempt to collect tickets or impose fines.

Image 4 - Food and storytelling during the Unfair Fare Dodge.

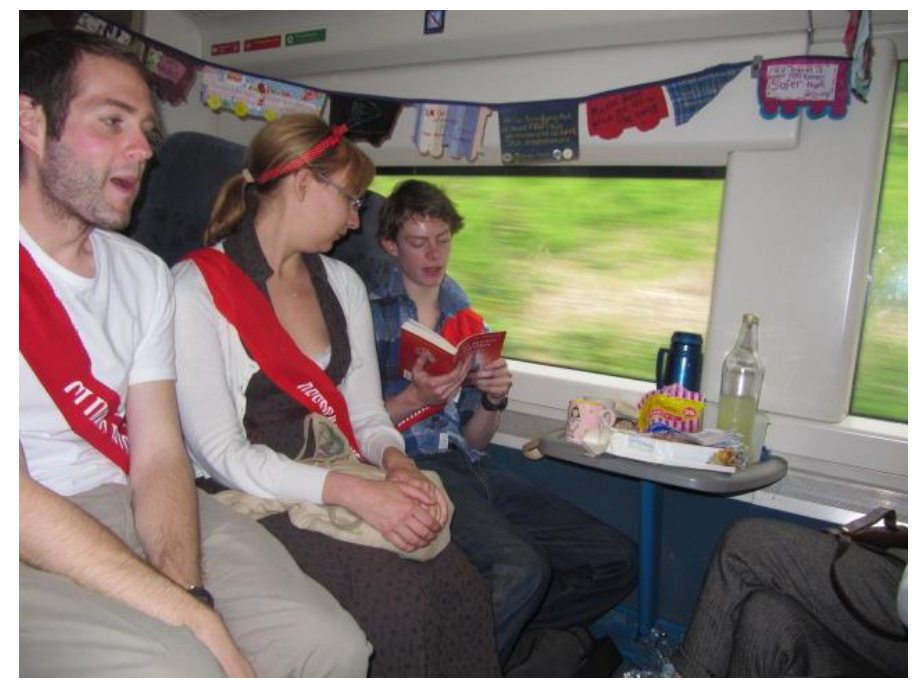


Once the group reached the destination another picnic was held near the train platform to celebrate the day's action (see image 5).

\section{Delivering the Stitched Petition}

In mid-May, the petition-train was presented to the transport minister, Philip Hammond at a transport conference, at which point the petition had grown to be 50-meters long (Craftivist Collective 2011c). Photographic evidence suggests that approximately 15 protesters presented the petition.

Domestically feminine elements in the Great Railway Adventure campaign

Based on the description of events above we can pin-point a variety of DFEs within protest events involving craft, clothing and food. This intentionally framed the protest with an emphasis on the Suffragettes or the domestic sphere. Intentional framing is the process of active engagement 'in the production and maintenance of meaning for constituents, antagonists, and bystanders or observers' (Benford and Snow 2000: 613), and in this case, according to conversations with Climate Rush organizers, the events were meant to produce novelty and a festive atmosphere both for participants and outside observers including the mass media (personal interview, 16 April, 2012). Prior to the stitch-ins, the 'railway adventure' blog featured a call to 'to help get local press coverage of your event' which linked to a press release template (http://railwayadventure.wordpress.com/2011/03/14/craftivism/). 
Image 5 - Setup of picnic at Canterbury Station, marking end of the Unfair Fare Dodge.

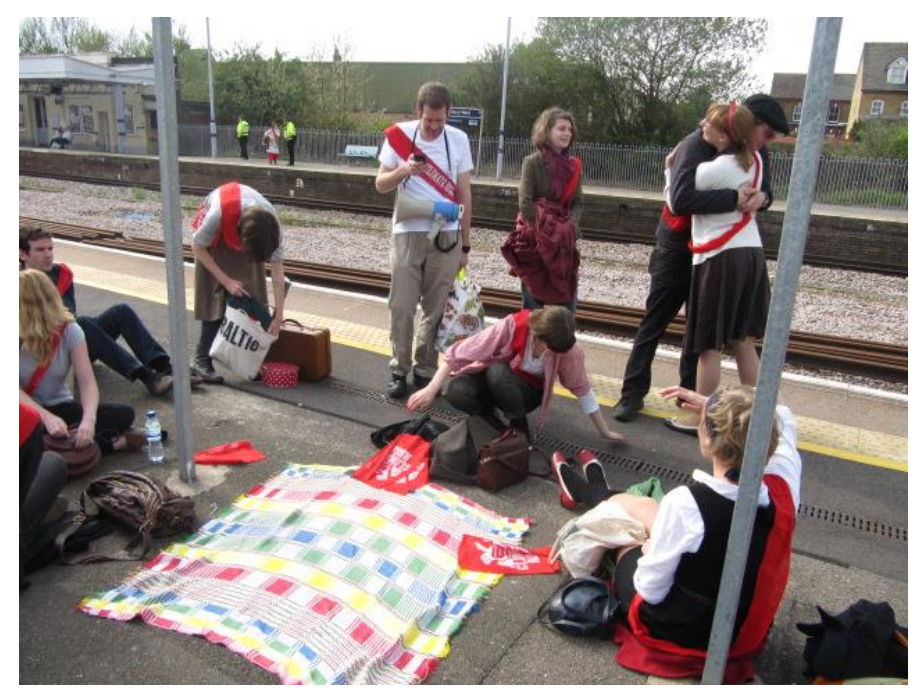

Not only were the DFEs used to frame the events in particular and novel ways, but they can also be seen to play a role in promoting the more typical features of contentious politics such as WUNC displays. Each of the displays (worthiness, unity, numbers, commitment) were exhibited during the course of the events and through the DFEs.

Worthiness was present in the organization of the event, including the coordination of dress, the preparedness shown through the provision of food, the construction of a petition, and the presence of participants widely ranging in age which may otherwise reduce worthiness when observed through the 'conventional wisdom which asserts that youth are “naturally” rebellious, or idealistic' (Flacks 1970: 340). Unity was shown through collective activity, matching dress, sashes, the breaking of bread, and marching together. This occurred in the stitch-ins but was particularly salient during the Unfair Fare Dodge. Numbers were shown both through the presence of participants as well as a very visual 
petition which was crafted in the initial protest events, displayed in the Dodge action and finally presented to a government official at the end of the campaign. Lastly, commitment was displayed through the quasi-illegality of actions, including collective stitching at the train stations. Again, this was particularly obvious during the direct action of the Unfair Fare Dodge where activists participated despite the threat of fines.

I have shown that the DFEs were used to produce frames and WUNC displays throughout the protest events that made up the Great Railway Adventure campaign. Now I will assess how these events were framed in news media coverage of the protest, paying particular attention to the DFEs.

Image 6 - Media taking an interest in rally.

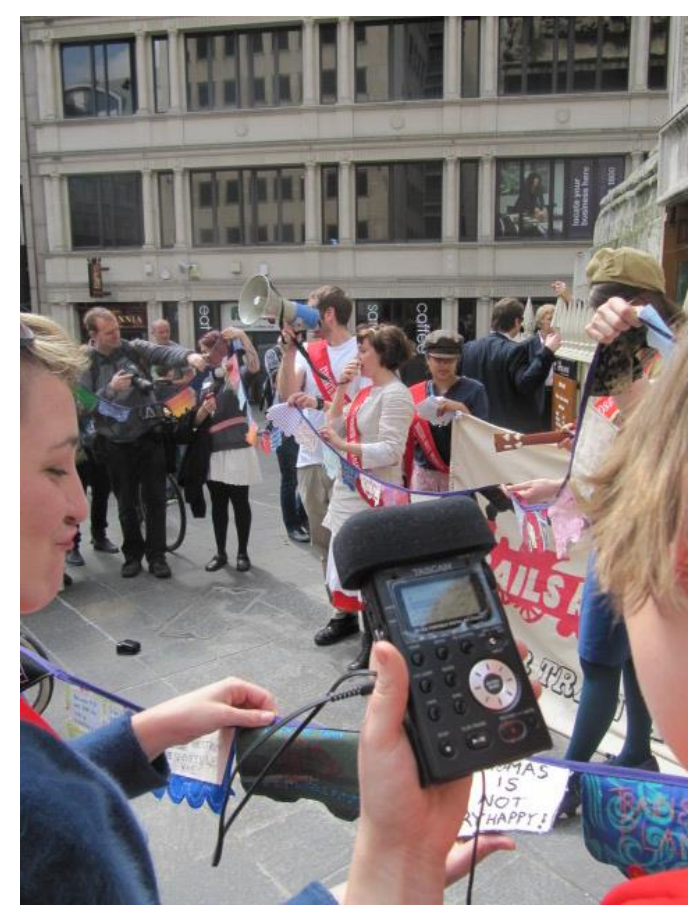




\section{$\underline{\text { Media Attention of Domestic Femininity in Protest }}$}

In the case of the Great Railway Adventure, campaigning organizations sought to highlight the issue of increases to train fares, and hoped to be able to force policymakers to either reduce the train fare increases or stop the increases entirely. As stated earlier, media exposure can be an indirect means of achieving policy change by influencing issue salience and public opinion that can pressure government action (see Burstein 1999, Kolb 2007). Protests are frequently associated with masculinity as images of violence, vandalism, and shouting have been the media's framing of direct action and protesters (see Einwohner et al. 2000). I will assess the level of exposure a campaign using DFEs was able to reach, and how the DFEs impacted the framing of news stories, and explore DFEs' abilities to open opportunities to the media.

\section{Comparative Analysis of News Articles}

As seen in Table 1, ten articles were found regarding the Great Railway Adventure, divided fairly evenly between local (6) and national (4) articles. Quantitatively, articles averaged 346 words, with a median of 172 words. This can be explained by the length of the one article exceeding 1,000 words. No articles made front page news, although data was missing for several articles using the Nexis ${ }^{\circledR}$ search. 
Table 1 - List of newspaper articles regarding the Great Railway Adventure campaign

\begin{tabular}{|l|l|l|l|l|l|}
\hline \multicolumn{1}{|c|}{ Title } & \multicolumn{1}{|c|}{ Newspaper } & Geography & $\begin{array}{c}\text { \# of } \\
\text { words }\end{array}$ & Page & Date \\
\hline $\begin{array}{l}\text { Londoner's Diary: On the Warpath for } \\
\text { Fairer Fares }\end{array}$ & $\begin{array}{l}\text { The Evening } \\
\text { Standard (London) }\end{array}$ & Local & 143 & N/A & 24 Mar \\
\hline $\begin{array}{l}\text { A protester with quite a pedigree: The } \\
\text { baronet's granddaughter charged with } \\
\text { defacing the Treasury who has } \\
\text { rebellion in the family }\end{array}$ & Daily Mail & National & 1728 & N/A & 31 Mar \\
\hline Crafty activists run a 'stitch-in' & Dorset Echo & Local & 143 & N/A & $5 \mathrm{Apr}$ \\
\hline Protesters to target spiralling rail fares & The Independent & National & 234 & 16 & $5 \mathrm{Apr}$ \\
\hline $\begin{array}{l}\text { 'We've been stitched up by fare } \\
\text { increases' }\end{array}$ & $\begin{array}{l}\text { Evening Post } \\
\text { (Bristol) }\end{array}$ & Local & 172 & 2 & $11 \mathrm{Apr}$ \\
\hline $\begin{array}{l}\text { Rail protesters rally with picnic on the } \\
\text { platform }\end{array}$ & Kentish Gazette & Local & 635 & N/A & $21 \mathrm{Apr}$ \\
\hline Rail users protest at fare rises & Medway News & Local & 228 & 5 & $21 \mathrm{Apr}$ \\
\hline $\begin{array}{l}\text { Passengers dodge fares in protest over } \\
\text { increase }\end{array}$ & $\begin{array}{l}\text { Sevenoaks } \\
\text { Chronicle }\end{array}$ & Local & 137 & 7 & $21 \mathrm{Apr}$ \\
\hline Stop The Rail Stitch-Up & Morning Star & National & 138 & N/A & $12 \mathrm{May}$ \\
\hline Rail protest is a real stitch-up & Metro & National & 78 & 4 & $13 \mathrm{May}$ \\
\hline
\end{tabular}

The first thing to note is that ten articles, six of which are in local newspapers, is not particularly high. However, the number of articles should be interpreted relative to the number of events and the WUNC displays involved, before judgment can be passed regarding DFEs. In order to test for this, a comparison should be made with another set of protests events. In order to compare, I use the case of Israeli Apartheid Week which took place 21-26 March 2011 in the UK. Israeli Apartheid Week in 2011 was said to be occurring in ' 87 cities around the world, with Britain having the largest number of them' (http://www.haaretz.com/news/diplomacy-defense/.premium-1.576201). According to the Israeli newspaper Haaretz, 


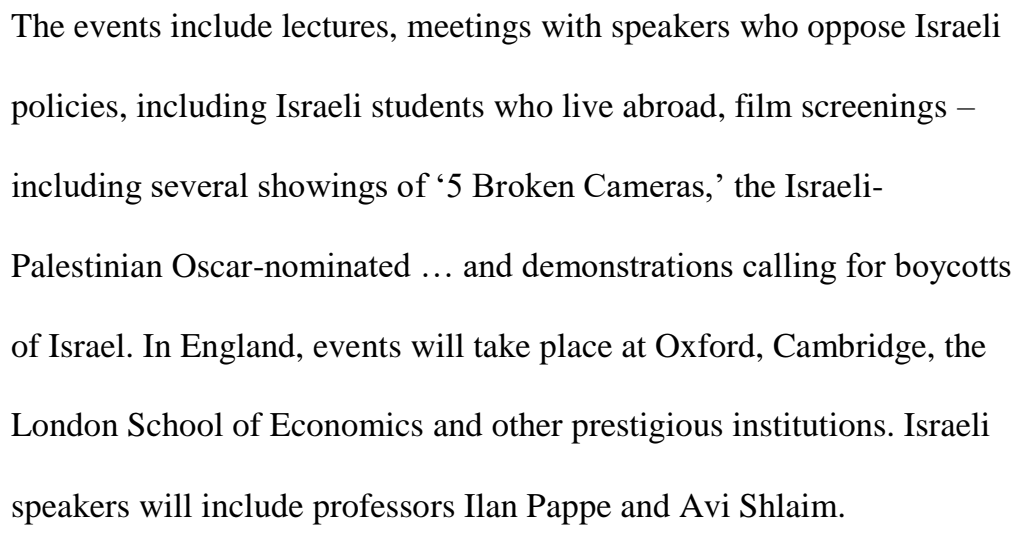

Despite the overrepresentation of the UK in these events, the sheer number of proposed events across the week, and the large number of participants around the country, news articles did not receive notable media attention. Running a Nexis® search from 19-27 March 2011, on 'Israel' OR 'Israeli' OR 'Palestine' OR 'Palestinian’ AND ‘Apartheid' OR 'protest' in the body of UK publications resulted in 135 articles with the majority regarding events within Israel and the occupied territories as well as the Arab Spring. In fact, no article was directly focused on the week of protests in the UK. A search for Israeli Apartheid Week provided no results. This suggests that novel DFEs may have been important in attracting media attention.

\section{$\underline{\text { Content Analysis of News Articles }}$}

Qualitatively, the articles in the search results heavily featured DFEs in their discussion of the protest. In a short blurb of the Evening Standard's Londoner's Diary section about Climate Rush founder Tamsin Omond, no mention of DFEs were made. The article which followed the Evening Standard's expose on Omond was likewise a human interest story, of the kind mass media has been shown to have an interest in regarding social movement 
actors (see Gitlin 2003; also see Salter 2009). Even so, the sentences that do discuss the campaign also describe DFEs:

\author{
Omond is urging her supporters to dress up in Victorian attire as \\ characters from the popular children's novel The Railway Children by \\ Edith Nesbit - red flannel petticoats, in particular, are to be encouraged \\ (along with jam sandwiches for lunch) (Davies 2011).
}

These descriptions of clothing and food are used throughout the article to contrast Omond, and Climate Rush, from conventional protests. 'Indeed, at a time when violent protest has become an all-too-common occurrence on the capital's streets, many regard Omond's tactics as rather quaint.... [She] is more likely to be wearing ankle-length Edwardian frocks than the hoodies and rucksacks worn by most protesters [sic]' (Davies 2011).

After descriptions of Omond's activism, the article returns to discussing the DFEs of Climate Rush actions: 'Dressed in her Pankhurst-style outfit, she and her predominantly female supporters handed out fairy cakes before flinging themselves against the doors of Parliament's St Stephen's entrance and demanding new policies to tackle global warming. She was photographed being dragged away in her frilly frock by police officers' (Davies 2011). While this can be seen as another example of media interest in DFEs it also suggests the opportunity DFEs provide to journalists. Namely, it allows the media to utilize the contrast between carnival ('frilly frock') and repression ('dragged away...by policy officers'), which provides the reader with a form of situational irony. Arguably this is only possible due to the novel nature of DFEs and existing stereotypes. 
One paragraph later, DFEs are discussed taking place in yet another Climate Rush action: '[I]n January 2009, she went on to host a mass Edwardian-themed picnic in the domestic departures lounge at Heathrow Airport's Terminal 1 in protest against plans for a third runway. It was attended by 250 supporters - and amused passengers and airport staff joined them on rugs to dine beneath parasols.' Here we see how the DFEs are shown as deescalating the disruptive action. Rather than framing the action as an unwanted disruption to the airport, this article uses DFEs to lighten the mood of the action, making reference to dress again later in the article (Davies 2011).

The next three articles focused on the stitch-in actions, with two articles published before the action and one the following day. The article in The Independent only made reference to DFEs in its mention of the planned stitch-ins but the article, albeit short, did not discuss any specific features of this protest that would suggest particular media interest in the DFEs (see Dutta 2011). The other two article's references to DFEs mostly came straight from the press release template that appeared on the campaign blog. Both the article and the template mention 'using scissors, thread and fabric' and stating that the group will 'hang bunting and lay picnic blankets', as well as references to 'jam sandwiches' (Dorset Echo 2011, also see Pearce 2011). Interestingly, the titles of the articles did not correspond with the press release whose title read 'Craftivists hold protest stitch-in at [YOUR LOCAL] railway station'. Instead, the two local articles that focused on stitch-ins used puns regarding craftivism. This may, however, be the product of titles suggested by the local collectives, rather than the newspapers themselves. Nevertheless, inclusion in the newspapers shows that the crafting elements of these protests were newsworthy. 
This can be seen more explicitly in the case of the Bristol article which appeared the day following the local stitch-in. 'However', the article reads, 'the group failed to attract the hundreds of supporters it had hoped for - in fact, only four people turned up'. Despite this low turnout, the event was able to make it into the paper (page 2) perhaps due to the novel nature of its DFEs.

The next three articles were from local papers and followed the Unfair Fare Dodge. The Kentish Gazette, covering the Canterbury area, gave the story 635 words which was the longest coverage specifically about the Great Railway Adventure campaign. Its title, again, brought DFEs to the forefront of the article by introducing it as 'Protesters ...Picnic on the Platform'. The first sentence of the article briefly describes the 'fare dodge' protesting increases in train ticket prices and is then immediately followed by reference to DFEs: 'Many travelled from London to Canterbury West dressed as characters from the Railway Children, where they unravelled a protest banner and had a picnic on the platform' (Claridge 2011). Again, the media quickly use the opportunity to discuss the protesters clothing and food. The article continues by quoting one protester and discussing the train company's openness to the activists. This openness could be a result of wanting to avoid a situation in which situational irony is revealed whereby 'polite' DFEs are used in a protest that is repressed then by police or train security personnel.

Another local article, published in both the Medway News and This is Kent first covered the basic details of the protest and the concerns over increased ticket prices. The only references to DFEs came in the form of interviews with the protesters who stated: 'It was the most fun I've had on the train in a long time. There were no delays, the staff were polite 
and we had music and jam sandwiches to entertain us on our way.' Here the tone of the protest was lightened from more traditional protest but the DFE mentioned, primarily food, could be seen as a relatively unnoticeable point in the article. Another protester stated later in the article: 'It was a brilliant day and a real carnival atmosphere', but no specific references were made to DFEs (Christie 2011). This was echoed in the third article which only referred to Climate Rush's 'involving and creative protest' which followed the mention of clothing. Both statements appeared in the last section of the article (also This is Kent 2011) and a very similar article was published by SkyNews (Sinclair 2011), which was not picked up in the Nexis ${ }^{\circledR}$ search.

When the stitched passenger car petition was given to a government official, articles appeared in three national papers (the Morning Star, Metro and The Express). The Morning Star, a left wing daily newspaper, again used the 'punny' title referring to a 'stitch-up' when it wrote about a petition that 'came in the form of a 50-metre piece of fabric featuring train carriages with hand-stitched messages' (Morning Star 2011), giving DFEs the first line of the article, and again suggesting it was useful for the media in 'selling the story', a major consideration in the publication of news stories (see Cooper and Ebeling 2007). The very short Metro (2011) article (78 words) again ran on the title of a 'stitch-up' and featured nearly the same article as the Morning Star, despite its less overtly political focus. The mention of a fabric petition is perhaps surprising for a tabloid which avoids discussing many political issues ${ }^{3}$. The similarity is due to the article's appearance on the Press Association wire service, which was not picked up by the Nexis ${ }^{\circledR}$ UK search. 
This article, also featured on MSN News UK (2011), did not feature a DFE in the title, instead reading: 'Group Hands over Rail Fare Petition'.

The analysis of ten articles found through a Nexis ${ }^{\circledR}$ UK search showed that the novelty of domestically feminine elements were attractive to newspaper editors at both the national and local level but only to a small degree. Half of the articles in the analysis featured a DFE in the title, all the DFEs were incorporated into the articles, and DFEs were used as lead-ins to the general story. Nevertheless, the total number of articles, with some not featuring DFEs, suggests that these elements were not newsworthy in themselves. Also, although the small Bristol stitch-in which was still able to be featured on page 2 of the Evening Post (Bristol), but other local stitch-ins in Brighton, Cornwall, Devon, Leeds, Sheffield, Manchester failed to attract this media attention.

The Unfair Fare Dodge, which started its journey in England's most populated city, had a modest turn out of approximately 50 people at the initial rally, with only approximately 35 people participating in the direct action. It is widely recognized that larger protest events are more likely to garner greater media attention (Oliver and Myers 1999) and it has been noted that 'On an average day in a random Western democracy, thousands of press statements are issues by a variety of parties, interest groups, and movement organizations, hundreds of demonstrations, meetings, strikes, vigils, and other protests are staged, and numerous press conferences vie for the attention of the public and policy-makers' (Koopmans 2004: 371). A brief glance at events between the months of March through May, 2011 on the London-based activist site Indymedia London reveals that an average of over 100 activist events took place in and around London each month. ${ }^{4}$ Like the case of the 
Israeli Apartheid Week events of 2011, not all events receive media attention. This perhaps suggests that there is power in DFEs, at their relatively novel present state, in achieving media attention despite modest levels of participation in events. However, media attention should increase with greater WUNC displays. We notice this as only two articles reported solely on the stitch-ins, with the majority of articles focusing on the better attended and more 'risky' Unfair Fare Dodge.

\section{$\underline{\text { Discussion }}$}

Vliengenthart and Walgrave (2012) have argued that '[m]ovements have to fight to get attention and when they get covered, it is far from certain that the news takes over their frame or interpretation of the issue' (388). My analysis has shown that DFEs, at least in their current novel state, can overcome the problem of attaining news media attention and avoid negative portrayals but cannot do so with great levels of exposure or certainty. However, when the topic was covered approximately half of the articles highlighted campaigners' uses of DFEs. This is perhaps due to other gendered stereotypes such as feminine fragility and gentleness (Gill 2007) in which the DFEs elicit sentiments that are averse to the more common perceptions of the 'all-too-common' violent protesters and therefore represents a type of new, gentle form of activism. Therefore, the novelty appears to produce enough currency to buy its way into the mass media in some instances, and the feminine nature of the novel acts positions itself in a way that is difficult to object to within traditional frames regarding protesters. 
Media coverage of the Great Railway Adventure campaign can be seen as significant but limited. Though one article appeared in a wire service, it was only picked up by two newspapers; in addition, the campaign only appeared in four national newspapers, of which one was a human interest article. Nevertheless, the campaign was able to achieve what many protests and organizations are unable to regarding news coverage while also being framed, for the most part, positively. The qualitative content analysis showed that DFEs were used to 'soften' the message and address the novel creativity in the protests. However, these novel elements still needed to occur within a more traditional protest context that was suitable for readers' preconceptions of protest such as marches, rallies and direct action. In addition, these DFEs may have also played a role in shifting the focus of the articles from the demands of the protest to the protest's embodied forms.

The case study has a far-reaching relevance to social movement organizations which plan events for the purposes of media attention. Results show there is potential for DFEs to be used for their novelty and eliciting situational irony by seemingly subverting standard notions of protest, but traditional means of achieving coverage, including greater WUNC displays, must also be incorporated in order for widespread media attention to occur. It should be noted however, that the novel nature of DFEs suggests that a saturation of such actions is likely to reduce coverage of future DFE-infused protest events.

\section{Acknowledgements}

I am grateful for the helpful suggestions given to me by Professor Christopher Rootes. 


\section{$\underline{\text { References }}$}

Andrews M (1997) The Acceptable Face of Feminism: the Women's Institute as a Social Movement. London: Lawrence \& Wishart.

Atkinson P and Hammersley M (1994) Ethnography and participant observation. In:

Denzin N K and Lincoln Y S (eds) Handbook of Qualitative Research. Thousand Oaks: Sage 248-260.

BBC News (2011) Rail fares to rise by 5.9\% from January. 20 December, 2011. Available at: http://www.bbc.co.uk/news/business-16260872

Beer D (2006) The Pop-Pickers Have Picked Decentralised Media: the Fall of Top of the Pops and the Rise of the Second Media Age. Sociological Research Online 11(3). Available at: http://www.socresonline.org.uk/11/3/beer.html.

Benford R D and Snow D A (2000) Framing Processes and Social Movements: An Overview and Assessment. Annual Review of Sociology 26: 611-639.

Bring Back British Rail (nd) Background. Available at: www.bringbackbritishrail.org/background.

Bristol Evening Post (2011) We've been stitched up by fare increases. 11 April, 2011. Burstein P (1998) Bringing the Public Back in: Should Sociologists Consider the Impact of Public Opinion on Public Policy? Social Forces 77(1): 27-62. 
Burstein P (1999) Social Movements and Public Policy. In: Giugni M, McAdam D and Tilly C (eds) How Social Movements Matter. Minneapolis: University of Minnesota Press 3-21.

Burstein P (2003) The Impact of Public Opinion on Public Policy: A Review and an Agenda. Political Research Quarterly 56(1): 29-40.

Burstein P and Linton A (2002) The Impact of Political Parties, Interest Groups, and Social Movement Organizations on Public Policy: Some Recent Evidence and Theoretical Concerns. Social Forces 81(2): 380-408.

Campaign For Better Transport (nd) Fair Fares Now. Available at: www.bettertransport.org.uk/fairfares.

Carroll W K and Ratner R S (1999) Media Strategies and Political Projects: A Comparative Study of Social Movements. The Canadian Journal of Sociology 24(1): 1-34.

Christie S (2011) Frustrated commuters stage fare-dodging protest at planned ticket price hike. This is Kent 21 April 2011.

Claridge A (2011) Rail protesters rally with picnic on the platform. Kentish Gazette 21 April 2011.

Climate Rush (nd) Our Actions. Available at: www.climaterush.co.uk/our-actions.

Climate Rush (2011) Railway Children invite DFT to pay fair rail fares. Available at: www.climaterush.co.uk/archives/390. 
Cooper G and Ebeling M (2007) Epistemology, Structure and Urgency: the Sociology of Financial and Scientific Journalists. Sociological Research Online 12(3): 8.

Cottle S (2008) Reporting demonstrations: The changing media politics of dissent. Media Culture Society 30:6(853-872).

Craftivist Collective (2011a) 10th April: Crafting a train of bunting to campaign for Fair Fares! 11 March, 2011. Available at: craftivist-collective.com/2011/03/11/crafting-a-trainof-bunting-to-campaign-for-fair-fares.

Craftivist Collective (2011b) Craftivists held protest stitch-in at railway stations across the UK last weekend. 11 April, 2011. Available at: craftivistcollective.com/2011/04/11/craftivists-held-protest-stitch-in-at-railway-stations-across-theuk-last-weekend.

Craftivist Collective (2011c) Our Train Bunting petition being used to challenge Transport Secretary Philip Hammond. 12 May, 2011. Available at: craftivistcollective.com/2011/05/12/our-train-bunting-petition-being-used-to-challenge-transportsecretary-philip-hammond.

Cresswell T (1994) Putting Women in their Place: The Carnival at Greenham Common. Antipode 26(1): 35-58.

Daily Mail (2009) Hundreds of green campaigners hold picnic protest at Heathrow in opposition to third runway plans. 13 January 2009. Available at: 
www.dailymail.co.uk/news/article-1113695/Hundreds-green-campaigners-hold-picnicprotest-Heathrow-opposition-runway-plans.html.

Davies B (2011) A Protester with Quite a Pedigree. The Daily Mail 18 May 2011.

Dellinger B (1999) The Structural Constraint of "Concision" as it is Used in the Discourse Style of American Commercial Broadcasting. In: Inkinen S (ed) Mediapolis: Research in Text Theory, Berlin: Walter de Gruyter \& Co 165-201.

Dorset Echo (2011) Crafty activists run a "stitch-in". 5 April Nexis. Web. Date Accessed: 11 December, 2013.

Dutta K (2011) Protesters to target spiralling rail fares. The Independent 5 April 2011.

Earl J, Martin A, McCarthy J D and Soule S A (2004) The Use of Newspaper Data in the Study of Collective Action. Annual Review of Sociology 30: 65-80.

Einwohner R L, Hollander J A and Olson T (2000) Engendering Social Movements:

Cultural Images and Movement Dynamics. Gender \& Society 14(5): 679-699.

Farrar Mrs J (1838) The Young Lady’s Friends. New York: Samuel S. \& William Wood.

Flacks R (1970) Social and Cultural Meanings of Student Revolt: Some Informal Comparative Observations. Social Problems 17(3): 340-357.

Gamson W A and Modigliani A (1989) Media Discourse and Public Opinion on Nuclear Power: A Constructionist Approach. American Journal of Sociology 95(1): 1-37. 
Gamson W A and Wolfsfeld G (1993) Movements and Media as Interacting Systems. Annals of the American Academy of Political and Social Science 528(1):114-25.

Gaventa J and McGee R (2010) Citizen Action and National Policy Reform. London: Zed Books.

Gill F (2007) "Violent” femininity: Women rugby players and gender negotiation. Women's Studies International Forum 30(5):416-426.

Gitlin T (2003) The Whole World is Watching: Mass Media in the Making and Unmaking of the New Left, Berkeley: University of California Press.

Giugni M G (1998) Was It Worth the Effort? The Outcomes and Consequences of Social Movements. Annual Review of Sociology 24: 571-593.

Giugni M (2004) Social Protest and Policy Change: Ecology, Antinuclear, and Peace Movements in Comparative Perspective. Oxford: Rowman \& Littlefield Publishers.

Glaister S (2004) British Rail Privatisation: Competition Destroyed by Politics. Centre for the Study of Regulated Industries, Occasional Paper 23.

Hsieh H-F and Shannon S E (2005) Three Approaches to Qualitative Content Analysis. Qualitative Health Research 15(9): 1277.

Jackson B (2011) Tesco targeted in CO2 protest. The Sun 22 March 2011.

Kent Online (2011) Railway Children protesters to "dodge fares”. 15 April 2011. 
King B G and Soule S A (2007) Social Movements as Extra-institutional Entrepreneurs: The Effect of Protests on Stock Price Returns. Administrative Science Quarterly 52(3): 413-442.

Kolb F (2007) Protest and Opportunities: The Political Outcomes of Social Movements. Chicago: The University of Chicago Press.

Koopmans R (2004) Movements and media: Selection processes and evolutionary dynamics in the public sphere. Theory and Society 33(3-4): 367-391.

Lawson S F (1991) Freedom Then, Freedom Now: The Historiography of the Civil Rights Movement. The American Historical Review 96(2): 456-471.

Mason R (2005) The Meaning and Value of Home-Based Craft. International Journal of Art \& Design Education 24: 261-268.

Mayhall L E N (1995) Creating the "Suffragette Spirit": British feminism and the historical imagination. Women's History Review 4(3): 319-344.

Metro (2011) Rail protest is a real stitch-up. Available at: eedition.metro.co.uk/2011/05/13/4.html.

Morning Star (2011) Stop the Rail Stitch-Up. Available at: www.morningstaronline.co.uk/news/content/view/full/104586.

MSN News UK (2011) Group hands over rail fare petition. Available at: news.uk.msn.com/articles.aspx?cp-documentid=157448690. 
Nesbit E (1993) The Railway Children. Ware: Wordsworth Editions.

Oliver P E and Myers D J (1999) How Events Enter the Public Sphere: Conflict, Location, and Sponsorship in Local Newspaper Coverage of Public Events. American Journal of Sociology 105(1): 38-87.

Patterson T E (1997) The News Media: An Effective Political Actor? Political Communication 14(4): 445-455.

Pearce L (2011) Stitch-in protest at Dorchester South station. Dorset ECHO 12 April 2011. Peirce K (1997) Women's Magazine Fiction: A Content Analysis of the Roles, Attributes, and Occupations of Main Characters. Sex Roles 37(7/8): 581-593.

Raeburn A (1973) The Militant Suffragettes. London: Michael Joseph.

Salter J (2009) Tamsin Omond: The climate change protester. The Telegraph 15 October 2009.

Sinclair L (2011) Protesters Rail Against “Unfair” Train Fares. Sky News 17 April 2011.

Sparrow A (2009) Climate protesters glue themselves around Parliament statue. The Guardian 27 April 2009.

Soroka S N (2003) Media, Public Opinion, and Foreign Policy. The International Journal of Press/Politics 8(1): 27-48.

Stewart M L (2005) The Politics and Spectacle of Fashion and Femininity. Journal of Women's History 17(1): 192-200. 
This Is Kent (2011) Passengers dodge fares in protest over increase. Available at: www.thisiskent.co.uk/Passengers-dodge-fares-protest-increase/story-11996189detail/story.html.

Tilly C (2006) Regimes and Repertoires. Chicago: The University of Chicago Press.

Van De Donk W, Loader B D, Nikon P G and Rucht D (eds) (2004) Cyberprotest: New Media, Citizens and Social Movements. Abingdon: Routledge.

Van Der Zee B (2009) The Most British of Protests. The Guardian 12 January 2009.

Available at: www.guardian.co.uk/environment/blog/2009/jan/12/activiststravelandtransport.

Verdon N (2010) “The Modern Countrywoman": Farm Women, Domesticity and Social Change in Interwar Britain. History Workshop Journal 70(1): 86-107.

Van Zoonen E A (1992) The Women's Movement and the Media: Constructing a Public Identity. European Journal of Communication 7(4): 453-476.

Vliegenthart R and Walgrave S (2012) The Interdependency of Mass Media and Social Movements. In: Semetko H A and Scammell M (eds) The SAGE Handbook of Political Communication. London: SAGE Publications 387-398.

De Vreese CH and Boomgaarden HG (2006) Media Effects on Public Opinion about the Enlargement of the European Union. Journal of Common Market Studies 44(2): 419-436.

Watson H (2011) Preconditions for Citizen Journalism: A Sociological Assessment. Sociological Research Online 16(3): 6 Available at:www.socresonline.org.uk/16/3/6.html. 
Welter B (1966) The Cult of True Womanhood: 1820 - 1860. American Quarterly 18(2):

151-174.

Young A (1990) Femininity in dissent. London: Routledge.

All photos are the work of the author.

\footnotetext{
1 'Journalists respond less to the pressing demand of issues than to the relentless churn of the news cycle. Each day is a fresh start, a new reality. Novelty is prized, as is certainty. Journalists must have a story to tell, and it must be different from yesterday's.' (Patterson 1997: 447).

${ }^{2}$ Articles with 'moderate' levels of similarity were removed. No additional relevant articles appeared when no duplicated articles were removed.
} 
${ }^{3}$ That same day the Metro's leading articles included a story of a Facebook-paid smear campaign against Google, a story about one of 'the millions of admirers of Pippa Middleton's bottom' and follow up articles on murder cases.

${ }^{4}$ 125, 84 and 96 protest events in March, April and May 2011 respectively, were found. 